\title{
Plant Toxin-Based Immunotoxins for Cancer Therapy: A Short Overview
}

\author{
Letizia Polito *, Alice Djemil and Massimo Bortolotti \\ Department of Experimental, Diagnostic and Specialty Medicine-DIMES, Alma Mater Studiorum, \\ University of Bologna, Via San Giacomo 14, 40126 Bologna, Italy; alice.djemil2@unibo.it (A.D.); \\ massimo.bortolotti2@unibo.it (M.B.) \\ * Correspondence: letizia.polito@unibo.it; Tel.: +39-0512094700; Fax: +39-0512094746 \\ Academic Editor: Vincenzo Cerullo \\ Received: 29 April 2016; Accepted: 30 May 2016; Published: 1 June 2016
}

\begin{abstract}
Immunotoxins are chimeric proteins obtained by linking a toxin to either an intact antibody or an antibody fragment. Conjugation can be obtained by chemical or genetic engineering, where the latter yields recombinant conjugates. An essential requirement is that the target molecule recognized by the antibody is confined to the cell population to be deleted, or at least that it is not present on stem cells or other cell types essential for the organism's survival. Hundreds of different studies have demonstrated the potential for applying immunotoxins to many models in pre-clinical studies and in clinical trials. Immunotoxins can be theoretically used to eliminate any unwanted cell responsible for a pathological condition. The best results have been obtained in cancer therapy, especially in hematological malignancies. Among plant toxins, the most frequently employed to generate immunotoxins are ribosome-inactivating proteins, the most common being ricin. This review summarizes the various approaches and results obtained in the last four decades by researchers in the field of plant toxin-based immunotoxins for cancer therapy.
\end{abstract}

Keywords: immunotoxin; immunotherapy; plant toxins; ribosome-inactivating proteins; cancer therapy

\section{Introduction}

More than one century ago, the Nobel Prize laureate Paul Ehrlich postulated the "magic bullet concept": drugs that go straight to their intended target cells. Since then, the idea of a drug selectively able to affect only the cells to be eliminated continues to fascinate thousands of researchers around the world.

Inspired by the magic bullet concept, one of the most popular research approaches is based on the linking of a pharmacologically active molecule to a carrier for selective delivery to target cells. Many different molecules have been exploited as carriers and as toxic moieties; the most studied are summarized in Table 1.

Table 1. Components of pharmacologically active conjugates.

\begin{tabular}{cc}
\hline Carrier & Toxic Moiety \\
\hline Antibodies & Drugs \\
Grow factors & Radioisotopes \\
Cytokines & Toxins \\
Hormones & Human enzymes \\
Antigens & - \\
Lectins & - \\
\hline
\end{tabular}


The pharmacologically active conjugates are primarily applied to research in the field of cancer therapy [1]. This research arose from the clinical use of radio- and chemotherapeutic agents, which have demonstrable anti-tumor effects but also limitations (considerable side effects due to the lack of selectivity for tumor cells, development of drug resistance, and occurrence of secondary malignancies). As a consequence, the study and development of alternative therapies, such as immunotherapy, were deeply stimulated in order to find therapies with greater specificity for transformed cells and less non-specific toxicity.

Various immunotherapeutic approaches are mainly focused on the identification of specific antigens on the surface of cancer cells. An essential requirement for this approach is that the target molecule is confined to the cell population to be destroyed, or at least that it is not present on stem cells or other cell types essential for the organism's survival. Antibodies are the most utilized carriers due to their stability in blood and avidity and affinity for their target antigen.

Both bacterial and plant toxins have been used as toxic moieties. The most commonly used bacterial toxic moieties are the Pseudomonas exotoxin and the diphtheria toxin, both of which inactivate elongation factor 2 (EF-2), causing irreversible protein synthesis arrest and subsequent cell death. Among plant toxins, ribosome-inactivating proteins (RIPs) are the most common. The use of toxins as pharmacologically active moieties of conjugates has some advantages in comparison with drugs, radionuclides, and enzymes:

1. As opposed to drugs that act in a stoichiometric ratio and only on dividing cells, toxins exert their action in a catalytic manner, do not induce drug resistance, and are able to kill cells in both dividing and quiescent states.

2. Radionuclides have the advantage of eliminating tumor cells that do not express the antigen or express a mutated antigen, but they also have different disadvantages, such as the unspecific toxicity for normal cells that surround the tumor, and the difficulties related to their manipulation, stability, and decay time.

3. In comparison to human enzymes, conjugated toxins have a much greater stability and activity against target cells.

\section{Immunotoxins (ITs)}

Immunotoxins (ITs) are chimeric proteins that are generally obtained by linking a toxin to an intact antibody or a fragment of an antibody. When toxins are linked to other carriers, they are more commonly referred to as "chimeric toxins" or "conjugates".

IT technology is the culmination of a therapeutic strategy originally devised by Köhler and Milstein in 1975 [2], in which hybridoma technology was introduced, allowing for large-scale production of monoclonal antibodies (mAbs) in mice. Recently, the development of recombinant DNA techniques permitted the generation of chimeric/humanized antibodies and engineered antibody fragments [3,4]. Thanks to numerous and continuous technical advances in the production of new mAbs and related fragments over the last decades, antibody-based immunotherapy has become a fast-growing field in cancer therapy, which has led to important achievements $[5,6]$. The clinical success of the chimeric (human-murine) anti-CD20 mAb rituximab, the first approved $\mathrm{mAb}$ for cancer treatment $[7,8]$, has prompted interest in the development of $\mathrm{mAb}$-based technologies, including ITs.

Until now, hundreds of studies have demonstrated the potential for IT application in many different models, both in pre-clinical studies and in clinical trials [9-12]. Theoretically, ITs could be used to eliminate any unwanted cell that is responsible for a pathological condition. Most ITs have been prepared to attack cancer cells, endothelial cells of tumor vasculature, immunocompetent cells, or virus-infected cells. The best results are in cancer therapy, especially hematological malignancies. Due to vascular accessibility, hematological cancers have a favorable setting for IT treatment. Furthermore, hematological cells are ideal targets for antibody-based immunotherapy due to the presence of clusters of differentiation (CD) on the cell surface. 
The efficiency of an IT in killing cells depends not only on the specific properties of the toxin and the carrier but also on characteristics of the target cell, including antigen density, binding affinity, and intracellular routing. Moreover, immunotherapy specificity is based on characteristics (surface antigens) that are completely independent from those associated with chemotherapy and radiotherapy. This specificity results in fewer side effects for non-target cells and enhanced cytotoxicity toward cell clones resistant to chemotherapy and radiotherapy.

Crucial to the design of an IT is the concerted effort of clinicians (to determine medical needs and models), immunologists (to select the most suitable mAbs), and basic scientists/pharmacologists (to choose the appropriate toxin and linker). An antibody and toxin can be conjugated by means of chemical linkage or by genetic engineering to obtain recombinant conjugates [13]. The choice of the modality to chemically link the antibody and the toxin is another fundamental step in IT design. In fact, the efficacy of an IT mainly depends on its capacity to deliver its toxic moiety into the target cell. The linker must meet some basic requirements: (i) to not impair the antigen-binding capacity of the carrier; (ii) to be stable in the plasma; (iii) to not release the toxin in the extracellular environment; and (iv) to release the toxin intact and in the cellular compartment where it can exert its enzymatic activity. To this end, a disulfide bridge is the most commonly used chemical linkage because such a bond exists in nature between the toxic and lectin subunits of toxins (see below). The presence of thio-disulfide oxidoreductase enzymes in the lysosome allows for breaking the bond and the subsequent release of the toxic payload. A disulfide bridge is obtained upon reaction of the antibody and toxin, previously derivatized using heterobifunctional reagents that are able to introduce thiol reactive groups in the two molecules. The most commonly used heterobifunctional reagents, able to insert thiol groups, are 2-iminothiolane and succinimidyl 3-(2-pyridyldithio)propionate. These reagents bind amino groups accessible on proteins, forming stable amide or imino bonds [14].

Recombinant ITs (also defined as second generation, in contrast with chemically obtained ITs, which are sometimes defined as first generation) are hybrid molecules in which the carrier and the toxin are fused by recombinant DNA techniques to obtain conjugates of smaller size to facilitate penetration into tumor masses [15]. The carrier moiety can be a single-chain variable fragment or a disulfide-stabilized variable fragment, in which a disulfide bond connects the two variable regions. The DNA sequences coding for the toxic agent and the ligand are cloned and expressed in yeast, bacteria, Chinese hamster ovary cells, or insect cells. The ITs produced in bacteria usually accumulate to high levels in "inclusion bodies", inside which ITs are often incorrectly folded, resulting in less active ITs compared to first generation ITs [16].

The main side effects reported in clinical trials with ITs are immunogenicity and vascular leak syndrome. The generation of anti-toxin antibodies can represent a serious obstacle in the continuation of treatment, mainly in carcinoma and sarcoma patients treated with ITs. Instead, in patients affected by hematological cancers, this side effect is less important, as these patients are often immunosuppressed [13]. Vascular leak syndrome is a consequence of a direct damage toward endothelial cells and is associated with fluid extravasation with edema, hypotension, and in severe form, signs of pulmonary and cardiovascular failure [17].

\section{Ribosome-Inactivating Proteins}

RIPs are a class of toxic enzymes that are widely distributed in the plant kingdom. RIP activity was first identified in rRNA $N$-glycosylase (EC 3.2.2.22) of the rat ribosome; RIPs specifically remove the A4324 adenine residue inside the GAGA sequence on the ricin/sarcin region of the $28 \mathrm{~S}$ rRNA in the $60 \mathrm{~S}$ subunit. Importantly, the GAGA sequence is universally conserved among eukaryotic rRNA. Adenine removal damages ribosomes in an irreversible manner, causing inhibition of protein synthesis [18]. RIPs also have in vitro $\mathrm{N}$-glycosylase activity on other substrates, such as DNA, mRNA, tRNA, and poly(A). For this reason, the definition of RIP enzymatic activity has been proposed to be changed to polynucleotide:adenosine glycosylase [19-21]. 
RIPs are mainly classified as type 1, consisting of a single-chain protein with enzymatic activity, or type 2, consisting of an enzymatic A-chain linked by a disulfide bond to a lectin B-chain that is able to bind to sugar-containing receptors on the cell membrane. The presence of the B-chain in type 2 RIPs allows for rapid internalization of the toxin into the cell. Inside the cell, the two moieties are separated and the active A-chain can enter the cytosol to exert its action. For this reason, most type 2 RIPs are quite toxic. However, a number of non-toxic type 2 RIPs were found in some plant species belonging to the Sambucus genus [22].

Despite the different toxicity reported in animals and cell systems [23], both type 1 and type 2 RIPs often show a similar activity on ribosomes in a cell-free system [24].

\section{Plant Toxin-Based Immunotoxins}

Despite a highly efficient cell-killing mechanism, toxins are limited by a lack of specificity. The mAbs have high selectivity for their target, but low cytocidal capacity. Both of these limitations can be overcome by conjugating the two moieties, thus building an IT.

An IT can trigger cell death by multiple death pathways (see Figure 1). Once the RIP reaches the cytosol, endoplasmic reticulum, or nucleus, it can induce activation of apoptosis, necroptosis, oxidative stress, as well as protein synthesis inhibition and potentially autophagy [25,26]. Moreover, the antibody can also activate cell death through apoptosis, or when whole antibodies are used, through complement-dependent cytotoxicity (CDC) and antibody-dependent cellular cytotoxicity (ADCC).

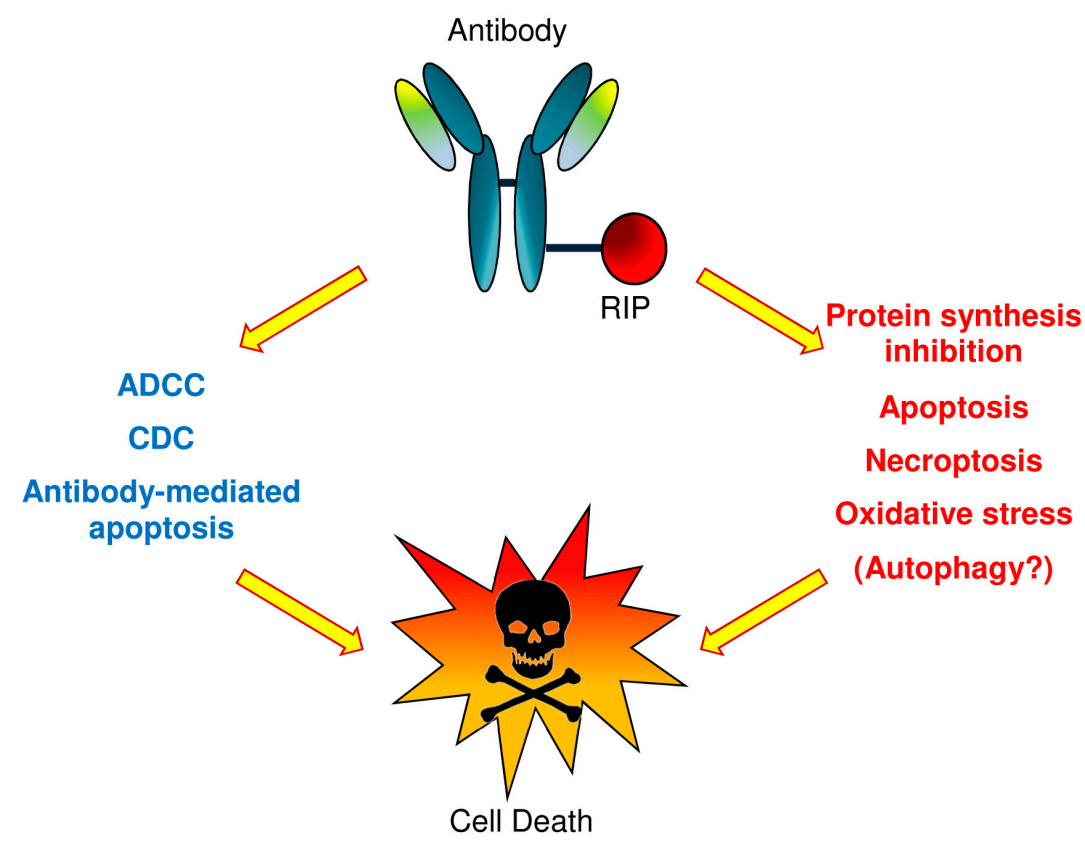

Figure 1. Plant toxin-based immunotoxins (type 1 RIPs or type 2 RIP A chains) can cause cell death by triggering multiple death pathways. Once the toxin reaches the cytosol, endoplasmic reticulum or nucleus, it can cause apoptosis activation, necroptosis, oxidative stress, the inhibition of protein synthesis and probably autophagy. Also, the antibody can activate cell death through apoptosis or through complement-dependent cytotoxicity (CDC) and antibody-dependent cellular cytotoxicity (ADCC), in the event that whole antibody molecules are used.

Ricin is the most commonly used type 2 RIP. The first ITs were prepared with ricin, binding the whole toxin to the $\mathrm{mAb}$, with the hope that antibody avidity and specificity would be able to confer to the conjugate a specific toxicity for the cell target much greater than the non-specific toxicity given by the B-chain. Despite having high efficiency, the high non-specific toxicity of these ITs has prevented their clinical use. Attempts to limit non-specific toxicity involve blocking, modifying, or deleting the 
lectin chain. Blocking the galactose binding domain in the B-chain was obtained by different means: (a) in vitro, by co-administration of excess of lactose or galactose in the culture medium; (b) by reaction with specific ligands, obtained by chemical modification of oligosaccharides; (c) by chemical bond with mAbs that sterically hinder binding to oligosaccharides [27].

A different approach is the use of only the A-chain, obtained by purification after chemical reduction of the A-B disulfide bridge or by genetic engineering. A large number of ITs have been constructed with the ricin A-chain (RTA). However, the use of RTA has also presented some problems, especially related to the difficulty and danger of its purification and non-specific toxicity due to the recognition of residues of mannose present on the A-chain by receptors present on many cell types. To address the problem of non-specificity, different ITs were prepared with the deglycosylated ricin A-chain (dgRTA).

Type 1 RIPs are also commonly used to obtain ITs. In comparison with RTA, type 1 RIPs are more stable, less dangerous, and easier to manipulate. Moreover, a wide variety of well-characterized type 1 RIPs is available, and often, they are immunologically not correlated with each other. These characteristics allow the selection of proteins with different properties that can be very useful in the construction of an IT, such as low systemic toxicity, high stability, etc.

The most studied type 1 RIPs for clinical applications as toxic components of ITs are PAP (pokeweed antiviral protein), gelonin, and above all, saporin-S6 [9,11,28]. The success of saporin-S6 derives from its strong activity both in cell-free systems and in cell lines. Moreover, it is extremely resistant to denaturation, high temperature, repeated freeze-thaw cycles, and proteolysis. Saporin-S6 is also stable with respect to chemical modifications, such as those required for derivatization and conjugation [29].

Despite the large number of research studies in vitro [30-35] or in animal models [11,36-39], a limited number of clinical trials have been conducted with type 1 RIP-containing ITs in comparison to dgRTA- or RTA-containing ITs (Table 2). Nevertheless, some type 1 RIPs, such as saporin, would have many advantages with respect to ricin, in terms of stability and efficacy, as described above [26]. Altogether, these characteristics render saporin-S6 an attractive molecule for the construction of immunoconjugates.

Table 2. Clinical trials with plant toxin-containing immunotoxins for cancer therapy \#.

\begin{tabular}{|c|c|c|c|c|c|}
\hline Immunotoxin & Antigen Target & RIP & Diseases & Clinical Phase & Ref. \\
\hline VB6-845 & EpCAM & deBouganin & Carcinoma & $\mathrm{I}$ & [40] \\
\hline HuM-195/rGel & CD33 & r-Gelonin & Leukemia & I & [41] \\
\hline B43-PAP & CD19 & PAP & ALL & $\mathrm{I} / \mathrm{II}$ & [42] \\
\hline H65-RTA & CD5 & RTA & CTCL & I & [43] \\
\hline T101-RTA & CD5 & RTA & CLL & $\mathrm{I}$ & [44] \\
\hline XOMAZYME-MEL & HMW mel. ag & RTA & Melanoma & I & {$[45,46]$} \\
\hline Combotox & CD19/CD22 & dgRTA & ALL, NHL & $\mathrm{I}$ & {$[47,48]$} \\
\hline 3A1-dgRTA & CD7 & dgRTA & T-LGL, ALL & II & [49] \\
\hline IgG-HD37-dgA & CD19 & dgRTA & NHL & $\mathrm{I}$ & [50] \\
\hline Xomazyme-791 & 72 kDa gp & dgRTA & Colon cancer & $\mathrm{I}$ & {$[51,52]$} \\
\hline RFT-5-dgA & IL-2R (CD25) & dgRTA & CTCL, Melanoma & $\mathrm{I} / \mathrm{II}$ & [53] \\
\hline Anti-B4-bR & CD19 & bRicin & NHL, Multiple myeloma & $\mathrm{I} / \mathrm{II}$ & {$[54,55]$} \\
\hline N901-bR & CD56 & bRicin & SCLC & $\mathrm{I}$ & [56] \\
\hline 260F9-rA & $55 \mathrm{kDa} g \mathrm{p}$ & RTA & Breast cancer & I & {$[57,58]$} \\
\hline Ber-H2-SO6 & CD30 & Saporin-S6 & HD & $\mathrm{I} / \mathrm{II}$ & {$[59,60]$} \\
\hline $\mathrm{F}\left(\mathrm{ab}^{\prime}\right) 2 \mathrm{BsAb}$ & CD22 & Saporin-S6 & NHL & I & {$[61,62]$} \\
\hline $4 \mathrm{~KB} 128+\mathrm{HD} 6$ & CD22 & Saporin-S6 & BCL & I & {$[63]$} \\
\hline
\end{tabular}

\# For more details about clinical trials, see the specific references. ALL: acute lymphoblastic leukemia; BCL: B-cell lymphoma; CD: cluster of differentiation; CLL: chronic lymphoblastic leukemia; CTCL: cutaneous T-cell lymphoma; dgRTA: deglycosylated ricin A chain; gp: glycoprotein; HD: Hodgkin's disease; NHL: non-Hodgkin's lymphoma; PAP: pokeweed antiviral protein; RTA: ricin A chain; RIP: ribosome-inactivating protein; SCLC: small cell lung carcinoma; T-LGL: T-cell large granular lymphocyte leukemia. 


\section{Conclusions}

Although more than a century has passed from Erlich's initial idea, the concept of ITs as a "magic bullet" for cancer therapy has not yet faded. In fact, new strategies to study and apply these hybrid molecules are underway, thanks to the availability of new generations of antibodies, such as chimeric or humanized molecules that are already used in clinical therapy. The great interest of institutional researchers and pharmaceutical companies in the field is also demonstrated in the number of patents protecting immunoconjugates or their components. It is the opinion of many investigators that immunoconjugates will likely become important players in cancer treatment in the near future (e.g., [63]). Recently, an anti-IL-2R IT containing dgRTA has been approved by the US Food and Drug Administration for the treatment of cutaneous T-cell lymphoma in adults $[13,53]$. The large number of antibody-drug conjugates and ITs in clinical trials supports the maturity of this approach [64].

Acknowledgments: This study was supported by the University of Bologna with funds for selected research topics and by Pallotti's Legacy for Cancer Research.

Conflicts of Interest: The authors declare no conflict of interest.

\section{Abbreviations}

The following abbreviations are used in this manuscript:

ALL: acute lymphoblastic leukemia; BCL: B-cell lymphoma; CD: cluster of differentiation; CLL: chronic lymphoblastic leukemia; CTCL: cutaneous T-cell lymphoma; dgRTA: deglycosylated ricin A chain; gp: glycoprotein; HD: Hodgkin's disease; IT: immunotoxin; mAb: monoclonal antibody; NHL: non-Hodgkin's lymphoma; PAP: pokeweed antiviral protein; RTA: ricin A chain; RIP: ribosome-inactivating protein; SCLC: small cell lung carcinoma; T-LGL: T-cell large granular lymphocyte leukemia.

\section{References}

1. Allen, T.M. Ligand-targeted therapeutics in anticancer therapy. Nat. Rev. Cancer 2002, 2, 750-763. [CrossRef] [PubMed]

2. Kohler, G.; Milstein, C. Continuous cultures of fused cells secreting antibody of predefined specificity. Nature 1975, 256, 495-497. [CrossRef] [PubMed]

3. Chames, P.; Baty, D. Antibody engineering and its applications in tumor targeting and intracellular immunization. FEMS Microbiol. Lett. 2000, 189, 1-8. [CrossRef] [PubMed]

4. Niv, R.; Cohen, C.J.; Denkberg, G.; Segal, D.; Reiter, Y. Antibody engineering for targeted therapy of cancer: Recombinant Fv-immunotoxins. Curr. Pharm. Biotechnol. 2001, 2, 19-46. [CrossRef] [PubMed]

5. Weiner, L.M.; Surana, R.; Wang, S. Monoclonal antibodies: Versatile platforms for cancer immunotherapy. Nat. Rev. Immunol. 2010, 10, 317-327. [CrossRef] [PubMed]

6. Reichert, J.M.; Rosensweig, C.J.; Faden, L.B.; Dewitz, M.C. Monoclonal antibody successes in the clinic. Nat. Biotechnol. 2005, 23, 1073-1078. [CrossRef] [PubMed]

7. Polito, L.; Mancuso, R.; Mercatelli, D.; Bortolotti, M.; Bolognesi, A. mAbs Targeting CD20 and Other Lymphocyte CD Markers in Lymphoma Treatment. In Monoclonal Antibodies in Oncology; Uckun, F.M., Ed.; Future Medicine: London, UK, 2013; pp. 6-19.

8. Polito, L.; Bortolotti, M.; Maiello, S.; Battelli, M.G.; Bolognesi, A. Rituximab and other new anti-CD20 mAbs for non-Hodgkin's lymphoma treatment. EMJ Oncol. 2014, 2, 63-69.

9. Bolognesi, A.; Polito, L. Immunotoxins and other conjugates: Pre-clinical studies. Mini Rev. Med. Chem. 2004, 4, 563-583. [CrossRef] [PubMed]

10. Frankel, A.E.; Kreitman, R.J.; Sausville, E.A. Targeted toxins. Clin. Cancer Res. 2000, 6, 326-334. [PubMed]

11. Polito, L.; Bortolotti, M.; Pedrazzi, M.; Bolognesi, A. Immunotoxins and other conjugates containing saporin-S6 for cancer therapy. Toxins 2011, 3, 697-720. [CrossRef] [PubMed]

12. Madhumathi, J.; Devilakshmi, S.; Sridevi, S.; Verma, R.S. Immunotoxin therapy for hematologic malignancies: Where are we heading? Drug Discov. Today 2016, 21, 325-332. [CrossRef] [PubMed]

13. FitzGerald, D.J.; Wayne, A.S.; Kreitman, R.J.; Pastan, I. Treatment of hematologic malignancies with immunotoxins and antibody-drug conjugates. Cancer Res. 2011, 71, 6300-6309. [CrossRef] [PubMed] 
14. Fracasso, G.; Bellisola, G.; Castelletti, D.; Tridente, G.; Colombatti, M. Immunotoxins and other conjugates: Preparation and general characteristics. Mini Rev. Med. Chem. 2004, 4, 545-562. [CrossRef] [PubMed]

15. Pastan, I.; Chaudhary, V.; FitzGerald, D.J. Recombinant toxins as novel therapeutic agents. Annu. Rev. Biochem. 1992, 61, 331-354. [CrossRef] [PubMed]

16. Shan, L.; Liu, Y.; Wang, P. Recombinant Immunotoxin Therapy of Solid Tumors: Challenges and Strategies. J. Basic Clin. Med. 2013, 2, 1-6. [PubMed]

17. Liu, X.Y.; Pop, L.M.; Schindler, J.; Vitetta, E.S. Immunotoxins constructed with chimeric, short-lived anti-CD22 monoclonal antibodies induce less vascular leak without loss of cytotoxicity. MAbs 2012, 4, 57-68. [CrossRef] [PubMed]

18. Stirpe, F.; Battelli, M.G. Ribosome-inactivating proteins: Progress and problems. Cell. Mol. Life Sci. 2006, 63, 1850-1866. [CrossRef] [PubMed]

19. Battelli, M.G.; Barbieri, L.; Bolognesi, A.; Buonamici, L.; Valbonesi, P.; Polito, L.; VanDamme, E.J.; Peumans, W.J.; Stirpe, F. Ribosome-inactivating lectins with polynucleotide:adenosine glycosidase activity. FEBS Lett. 1997, 408, 355-359. [CrossRef]

20. Barbieri, L.; Bolognesi, A.; Valbonesi, P.; Polito, L.; Olivieri, F.; Stirpe, F. Polynucleotide:adenosina glycosidase activity of immunotoxins containing ribosome-inactivating proteins. J. Drug Target. 2000, 8, 281-288. [CrossRef] [PubMed]

21. Bolognesi, A.; Polito, L.; Lubelli, C.; Barbieri, L.; Parente, A.; Stirpe, F. Ribosome-inactivating and adenine polynucleotide glycosylase activities in Mirabilis jalapa L. tissues. J. Biol. Chem. 2002, 277, 13709-13716. [CrossRef] [PubMed]

22. Ferreras, J.M.; Citores, L.; Iglesias, R.; Jiménez, P.; Girbés, T. Use of ribosome-inactivating proteins from Sambucus for the construction of immunotoxins and conjugates for cancer therapy. Toxins 2011, 3, 420-441. [CrossRef] [PubMed]

23. Battelli, M.G. Cytotoxicity and toxicity to animals and humans of ribosome-inactivating proteins. Mini Rev. Med. Chem. 2004, 4, 513-521. [CrossRef] [PubMed]

24. Stirpe, F. Ribosome-inactivating proteins: From toxins to useful proteins. Toxicon 2013, 67, 12-16. [CrossRef] [PubMed]

25. Polito, L.; Bortolotti, M.; Farini, V.; Battelli, M.G.; Barbieri, L.; Bolognesi, A. Saporin induces multiple death pathways in lymphoma cells with different intensity and timing as compared to ricin. Int. J. Biochem. Cell. Biol. 2009, 41, 1055-1061. [CrossRef] [PubMed]

26. Polito, L.; Bortolotti, M.; Pedrazzi, M.; Mercatelli, D.; Battelli, M.G.; Bolognesi, A. Apoptosis and necroptosis induced by stenodactylin in neuroblastoma cells can be completely prevented through caspase inhibition plus catalase or necrostatin-1. Phytomedicine 2016, 23, 32-41. [CrossRef] [PubMed]

27. Tyagi, N.; Tyagi, M.; Pachauri, M.; Ghosh, P.C. Potential therapeutic applications of plant toxin-ricin in cancer: Challenges and advances. Tumour Biol. 2015, 36, 8239-8246. [CrossRef] [PubMed]

28. Polito, L.; Bortolotti, M.; Mercatelli, D.; Battelli, M.G.; Bolognesi, A. Saporin-S6: A useful tool in cancer therapy. Toxins 2013, 5, 1698-1722. [CrossRef] [PubMed]

29. Bolognesi, A.; Tazzari, P.L.; Tassi, C.; Gromo, G.; Gobbi, M.; Stirpe, F. A comparison of anti-lymphocyte immunotoxins containing different ribosoma-inactivating proteins and antibodies. Clin. Exp. Immunol. 1992, 89, 341-346. [CrossRef] [PubMed]

30. Bolognesi, A.; Polito, L.; Farini, V.; Bortolotti, M.; Tazzari, P.L.; Ratta, M.; Ravaioli, A.; Horenstein, A.L.; Stirpe, F.; Battelli, M.G.; et al. CD38 as a target of IB4 mAb carrying SAP-S6: Design of an IT for ex vivo depletion of hematological CD38+ neoplasia. J. Biol. Regul. Homeost. Agents 2005, 19, 145-152. [PubMed]

31. Polito, L.; Bolognesi, A.; Tazzari, P.L.; Farini, V.; Lubelli, C.; Zinzani, P.L.; Ricci, F.; Stirpe, F. The conjugate Rituximab/SAP-S6 completely inhibits clonogenic growth of CD20-expressing cells and produces a synergistic toxic effect with Fludarabine. Leukemia 2004, 18, 1215-1222. [CrossRef] [PubMed]

32. Polito, L.; Bortolotti, M.; Farini, V.; Pedrazzi, M.; Tazzari, P.L.; Bolognesi, A. ATG-saporin-S6 immunotoxin: A new potent and selective drug to eliminate activated lymphocytes and lymphoma cells. Br. J. Haematol. 2009, 147, 710-718. [CrossRef] [PubMed]

33. Vooijs, W.C.; Otten, H.G.; van Vliet, M.; van Dijk, A.J.; de Weger, R.A.; de Boer, M.; Bohlen, H.; Bolognesi, A.; Polito, L.; de Gast, G.C. B7-1 (CD80) as target for immunotoxin therapy for Hodgkin's disease. Br. J. Cancer 1997, 76, 1163-1169. [CrossRef] [PubMed] 
34. Vooijs, W.C.; Post, J.; Wijdenes, J.; Schuurman, H.J.; Bolognesi, A.; Polito, L.; Stirpe, F.; Bast, E.J.; de Gast, G.C. Efficacy and toxicity of plasma-cell-reactive monoclonal antibodies B-B2 and B-B4 and their immunotoxins. Cancer Immunol. Immunother. 1996, 42, 319-328. [CrossRef] [PubMed]

35. Bolognesi, A.; Polito, L.; Tazzari, P.L.; Lemoli, R.M.; Lubelli, C.; Fogli, M.; Boon, L.; de Boer, M.; Stirpe, F. In vitro anti-tumour activity of anti-CD80 and anti-CD86 immunotoxins containing type 1 ribosome-inactivating proteins. Br. J. Haematol. 2000, 110, 351-361. [CrossRef] [PubMed]

36. Bolognesi, A.; Tazzari, P.L.; Olivieri, F.; Polito, L.; Lemoli, R.; Terenzi, A.; Pasqualucci, L.; Falini, B.; Stirpe, F. Evaluation of immunotoxins containing single-chain ribosome-inactivating proteins and an anti-CD22 monoclonal antibody (OM124): In vitro and in vivo studies. Br. J. Haematol. 1998, 101, 179-188. [CrossRef] [PubMed]

37. Pasqualucci, L.; Wasik, M.; Teicher, B.A.; Flenghi, L.; Bolognesi, A.; Polito, L.; Stirpe, F.; Falini, B.; Kadin, M.E. Antitumor activity of anti-CD30 immunotoxin (Ber-H2/saporin) in vitro and in severe combined immunodeficiency disease mice xenografted with human CD30+ anaplastic large-cell lymphoma. Blood 1995, 85, 2139-2146. [PubMed]

38. Di Massimo, A.M.; Di Loreto, M.; Pacilli, A.; Raucci, G.; D’Alatri, L.; Mele, A.; Bolognesi, A.; Polito, L.; Stirpe, F.; De Santis, R. Immunoconjugates made of an anti-EGF receptor monoclonal antibody and type 1 ribosome-inactivating proteins from Saponaria ocymoides or Vaccaria pyramidata. Br. J. Cancer 1997, 75, 822-828. [CrossRef] [PubMed]

39. Terenzi, A.; Bolognesi, A.; Pasqualucci, L.; Flenghi, L.; Pileri, S.; Stein, H.; Kadin, M.; Bigerna, B.; Polito, L.; Tazzari, P.L.; et al. Anti-CD30 (BER-H2) immunotoxins containing the type-1 ribosome-inactivating proteins momordin and PAP-S (pokeweed antiviral protein from seeds) display powerful antitumour activity against CD30+ tumour cells in vitro and in SCID mice. Br. J. Haematol. 1996, 92, 872-879. [CrossRef] [PubMed]

40. Kowalski, M.; Brazas, L.; Zaretsky, R.; Rasamoelisolo, M.; MacDonald, G.; Cuthbert, W.; Glover, N. A Phase I study of VB6-845, an anti-EpCAM fusion protein targeting advanced solid tumours of epithelial origin: Preliminary results. In Proceedings of the 2008 ASCO Annual Meeting (Post-Meeting Edition), Chicago, IL, USA, 2008.

41. Borthakur, G.; Rosenblum, M.G.; Talpaz, M.; Daver, N.; Ravandi, K.F.; Faderl, S.; Freireich, E.J.; Kadia, T.; Garcia-Manero, G.; Kantarjian, H.; et al. Phase I clinical trial of the anti-CD33 immunotoxin HuM195/rgel in patients with advanced myeloid malignancies. Haematologica 2013, 98, 217-221. [CrossRef] [PubMed]

42. Meany, H.J.; Seibel, N.L.; Krailo, M.; Villaluna, D.; Chen, Z.; Gaynon, P.; Neglia, J.P.; Park, J.R.; Hutchinson, R.; Sato, J.K.; et al. Feasibility Study of a Novel Experimental Induction Protocol Combining B43-PAP (Anti-CD19) Immunotoxin With Standard Induction Chemotherapy in Children and Adolescents With Relapsed B-Lineage ALL: A Report From the Children's Oncology Group. J. Immunother. 2015, 38, $299-305$. [CrossRef] [PubMed]

43. LeMaistre, C.F.; Rosen, S.; Frankel, A.; Kornfeld, S.; Saria, E.; Meneghetti, C.; Drajesk, J.; Fishwild, D.; Scannon, P.; Byers, V. Phase I trial of H65-RTA immunoconjugate in patients with cutaneous T-cell lymphoma. Blood 1991, 78, 1173-1182. [PubMed]

44. Hertler, A.; Schlossman, D.; Borowitz, M.; Blythman, H.; Casellas, P.; Frankel, A. An anti-CD5 immunotoxin for chronic lymphocytic leukemia: Enhancement of cytotoxicity with human serum albumin-monensin. Int. J. Cancer 1989, 43, 215-219. [CrossRef] [PubMed]

45. Spitler, L.E.; del Rio, M.; Khentigan, A.; Wedel, N.I.; Brophy, N.A.; Miller, L.I.; Harkonen, W.S.; Rosendorf, L.L.; Lee, H.M.; Mischak, R.P.; et al. Therapy of patients with malignant melanoma using a monoclonal antimelanoma antibody-ricin A chain immunotoxin. Cancer Res. 1987, 47, 1717-1723. [PubMed]

46. Selvaggi, K.; Saria, E.A.; Schwartz, R.; Vlock, D.R.; Ackerman, S.; Wedel, N.; Kirkwood, J.M.; Jones, H.; Ernstoff, M.S. Phase I/II study of murine monoclonal antibody-ricin A chain (XOMAZYME-Mel) immunoconjugate plus cyclosporine A in patients with metastatic melanoma. J. Immunother. Emphas. Tumor Immunol. 1993, 13, 201-207. [CrossRef]

47. Herrera, L.; Bostrom, B.; Gore, L.; Sandler, E.; Lew, G.; Schlegel, P.G.; Aquino, V.; Ghetie, V.; Vitetta, E.S.; Schindler, J. A Phase 1 study of combotox in pediatric patients with refractory B-lineage acute lymphoblastic leukemia. J. Pediatr. Hematol. Oncol. 2009, 31, 936-941. [CrossRef] [PubMed] 
48. Schindler, J.; Gajavelli, S.; Ravandi, F.; Shen, Y.; Parekh, S.; Braunchweig, I.; Barta, S.; Ghetie, V.; Vitetta, E.; Verma, A. A Phase I study of a combination of anti-CD19 and anti-CD22 immunotoxins (Combotox) in adult patients with refractory B-lineage acute lymphoblastic leukaemia. Br. J. Haematol. 2011, 154, 471-476. [CrossRef] [PubMed]

49. Frankel, A.E.; Laver, J.H.; Willingham, M.C.; Burns, L.J.; Kersey, J.H.; Vallera, D.A. Therapy of patients with T-cell lymphomas and leukemias using an anti-CD7 monoclonal antibody-ricin A chain immunotoxin. Leuk. Lymphoma 1997, 26, 287-298. [CrossRef] [PubMed]

50. Stone, M.J.; Sausville, E.A.; Fay, J.W.; Headlee, D.; Collins, R.H.; Figg, W.D.; Stetler-Stevenson, M.; Jain, V.; Jaffe, E.S.; Solomon, D.; et al. A Phase I study of bolus versus continuous infusion of the anti-CD19 immunotoxin, IgG-HD37-dgA, in patients with B-cell lymphoma. Blood 1996, 88, 1188-1197. [PubMed]

51. Byers, V.S.; Rodvien, R.; Grant, K.; Durrant, L.G.; Hudson, K.H.; Baldwin, R.W.; Scannon, P.J. Phase I study of monoclonal antibody-ricin A chain immunotoxin XomaZyme-791 in patients with metastatic colon cancer. Cancer Res. 1989, 49, 6153-6160. [PubMed]

52. LoRusso, P.M.; Lomen, P.L.; Redman, B.G.; Poplin, E.; Bander, J.J.; Valdivieso, M. Phase I study of monoclonal antibody-ricin A chain immunoconjugate Xomazyme-791 in patients with metastatic colon cancer. Am. J. Clin. Oncol. 1995, 18, 307-312. [CrossRef] [PubMed]

53. Schnell, R.; Borchmann, P.; Staak, J.O.; Schindler, J.; Ghetie, V.; Vitetta, E.S.; Engert, A. Clinical evaluation of ricin A-chain immunotoxins in patients with Hodgkin's lymphoma. Ann. Oncol. 2003, 14, 729-736. [CrossRef] [PubMed]

54. Grossbard, M.L.; Fidias, P.; Kinsella, J.; O’Toole, J.; Lambert, J.M.; Blattler, W.A.; Esseltine, D.; Braman, G.; Nadler, L.M.; Anderson, K.C. Anti-B4-blocked ricin: A phase II trial of 7 day continuous infusion in patients with multiple myeloma. Br. J. Haematol. 1998, 102, 509-515. [CrossRef] [PubMed]

55. Grossbard, M.L.; Lambert, J.M.; Goldmacher, V.S.; Spector, N.L.; Kinsella, J.; Eliseo, L.; Coral, F.; Taylor, J.A.; Blattler, W.A.; Epstein, C.L.; et al. Anti-B4-blocked ricin: A Phase I trial of 7-day continuous infusion in patients with B-cell neoplasms. J. Clin. Oncol. 1993, 11, 726-737. [PubMed]

56. Lynch, T.J.; Lambert, J.M.; Coral, F.; Shefner, J.; Wen, P.; Blattler, W.A.; Collinson, A.R.; Ariniello, P.D.; Braman, G.; Cook, S.; et al. Immunotoxin therapy of small-cell lung cancer: A Phase I study of N901-blocked ricin. J. Clin. Oncol. 1997, 15, 723-734. [CrossRef] [PubMed]

57. Gould, B.J.; Borowitz, M.J.; Groves, E.S.; Carter, P.W.; Anthony, D.; Weiner, L.; Frankel, A.E. Phase I study of an anti-breast cancer immunotoxin by continuous infusion: Report of a targeted toxic effect not predicted by animal studies. J. Natl. Cancer Inst. 1989, 81, 775-781. [CrossRef] [PubMed]

58. Weiner, L.M.; O’Dwyer, J.O.; Kitson, J.; Comis, R.L.; Frankel, A.E.; Bauer, R.J.; Konrad, M.S.; Groves, E.S. Phase I evaluation of an anti-breast carcinoma monoclonal antibody 260F9-recombinant ricin A chain immunoconjugate. Cancer Res. 1989, 49, 4062-4067. [PubMed]

59. Falini, B.; Bolognesi, A.; Flenghi, L.; Tazzari, P.L.; Broe, M.K.; Stein, H.; Dürkop, H.; Aversa, F.; Corneli, P.; Pizzolo, G.; et al. Response of refractory Hodgkin's disease to monoclonal anti-CD30 IT. Lancet 1992, 339, 1195-1196. [CrossRef]

60. Pasqualucci, L.; Flenghi, L.; Terenzi, A.; Bolognesi, A.; Stirpe, F.; Bigerna, B.; Falini, B. IT therapy of hematological malignancies. Haematologica 1995, 80, 546-556. [PubMed]

61. Bonardi, M.A.; Bell, A.; French, R.R.; Gromo, G.; Hamblin, T.; Modena, D.; Tutt, A.L.; Glennie, M.J. Initial experience in treating human lymphoma with a combination of bispecific antibody and SAP. Int. J. Cancer Suppl. 1992, 7, 73-77. [PubMed]

62. French, R.R.; Bell, A.J.; Hamblin, T.J.; Tutt, A.L.; Glennie, M.J. Response of B-cell lymphoma to a combination of bispecific antibodies and SAP. Leuk. Res. 1996, 20, 607-617. [CrossRef]

63. French, R.R.; Hamblin, T.J.; Bell, A.J.; Tutt, A.L.; Glennie, M.J. Treatment of B-cell lymphomas with combination of bispecific antibodies and SAP. Lancet 1995, 346, 223-224. [CrossRef]

64. Dosio, F.; Stella, B.; Cerioni, S.; Gastaldi, D.; Arpicco, S. Advances in anticancer antibody-drug conjugates and immunotoxins. Recent Pat. Anticancer Drug Discov. 2014, 9, 35-65. [CrossRef] [PubMed]

(C) 2016 by the authors; licensee MDPI, Basel, Switzerland. This article is an open access article distributed under the terms and conditions of the Creative Commons Attribution (CC-BY) license (http:/ / creativecommons.org/licenses/by/4.0/). 